\title{
Locally aggressive cavernous haemangioma of the mandible: an unusual presentation
}

\author{
Satya Ranjan Misra, ${ }_{1}^{1}$ Varun Rastogi, ${ }^{2}$ Neeta Mohanty, ${ }^{3}$ Daniel Alex Vineet ${ }^{4}$
}

${ }^{1}$ Institute of Dental Sciences, Siksha O' Ansuandhan University, Bhubaneswar, Odisha, India

${ }^{2}$ Department of Oral Pathology \& Microbiology, Kalka Dental College, Meerut, Uttar

Pradesh, India

${ }^{3}$ Department of Oral Pathology \& Microbiology, Institute of Dental Sciences, Siksha O' Ansuandhan University, Bhubaneswar, Odisha, India ${ }^{4}$ Department of Oral Medicine \& Radiology, PMS College of Dental Science \& Research, Thiruvananthapuram, Kerala, India

\section{Correspondence to}

Professor Neeta Mohanty, drneeta2014@gmail.com

Accepted 1 March 2015
CrossMark

To cite: Misra SR, Rastogi V, Mohanty N, et al. BMJ Case Rep Published online: [please include Day Month Year] doi:10.1136/ bcr-2014-208975

\section{DESCRIPTION}

Intraosseous haemangiomas, especially of the jaw bones, are rare benign vasoformative neoplasms of endothelial origin. They usually present as a firm, painless swelling of the jaw bone with or without facial asymmetry. ${ }^{1}$ Occasionally bleeding from the gingiva, mobility of teeth, pulsations, audible bruits and paraesthesia may occur. Clinically, the lesion may mimic ameloblastoma, arteriovenous malformation, central giant cell granuloma and aneurysmal bone cyst.

Radiographically, a multilocular radiolucency with ill-defined margins is seen. CT, MRI and angiography may be needed to delineate the lesion. ${ }^{2}$ Since the radiological appearance is not pathognomonic, ameloblastoma, central giant cell granuloma, osteosarcoma, odontogenic myxoma, dentigerous cyst, fibrous dysplasia, keratocystic odontogenic tumour, aneurysmal bone cyst, schwannoma of inferior alveolar nerve and multiple myeloma may be considered in the differential diagnosis.

Histologically, haemangiomas consist of a mass of endothelial cells forming vascular spaces of

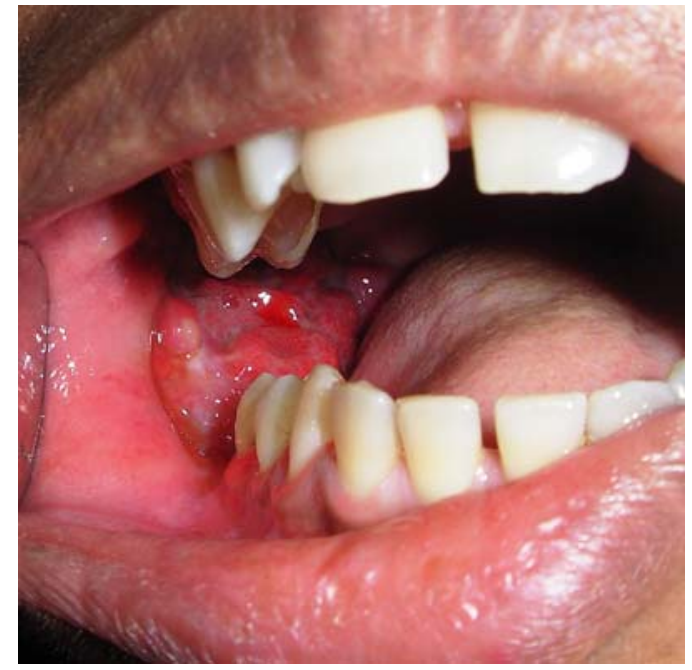

Figure 1 An irregular erythematous growth seen on the right retromolar region with surface ulceration.

varying size, interspersed with fibrous connective tissue stroma and bony trabeculae. ${ }^{1}$
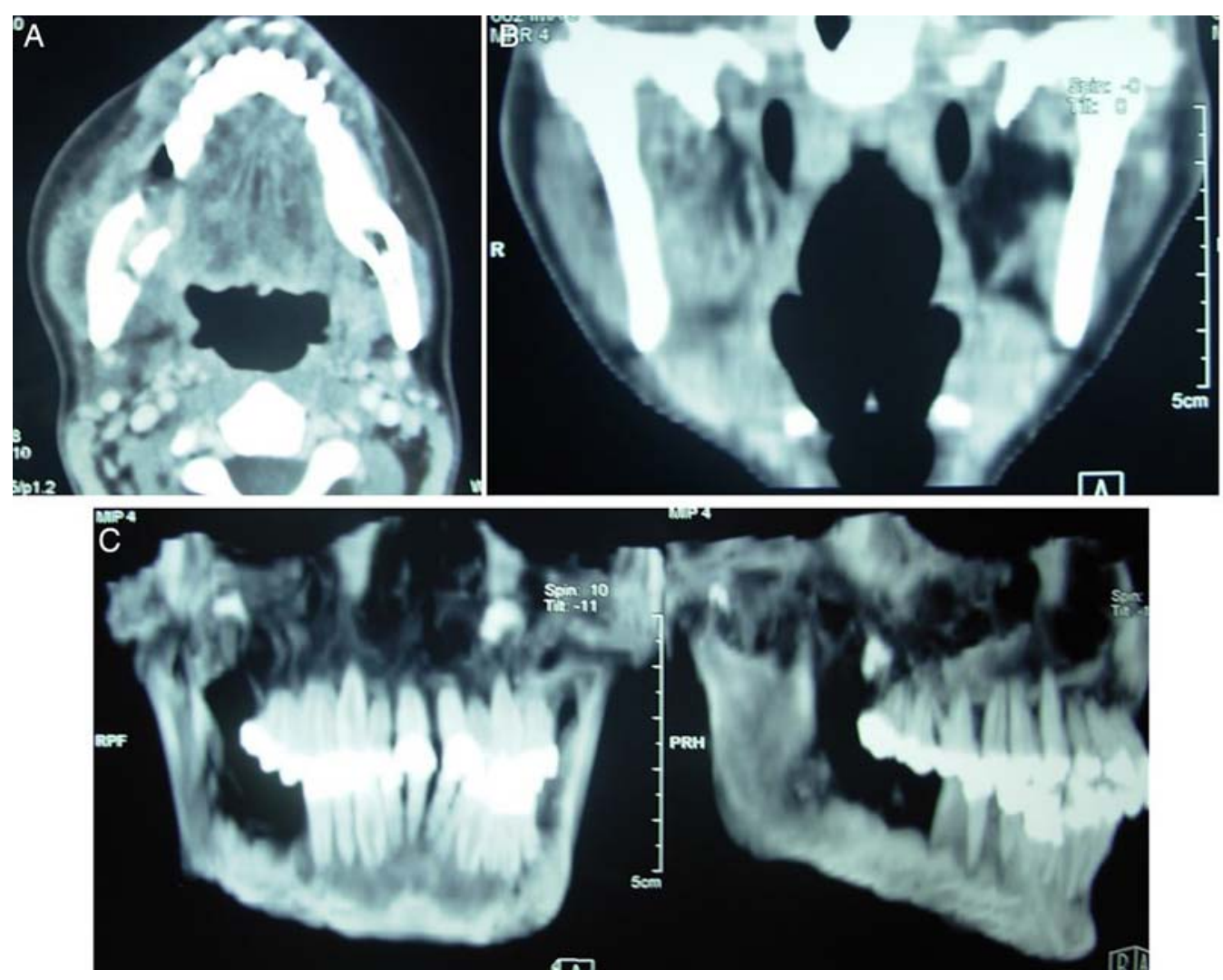

Figure 2 CT scan showing expansile lesion in the right body of the mandible with bicortical destruction in axial section (A), soft tissue growth in coronal section (B) and irregular bone destruction with bony spicules seen in the right mandibular alveolus in the three-dimensional CT scan (C). 


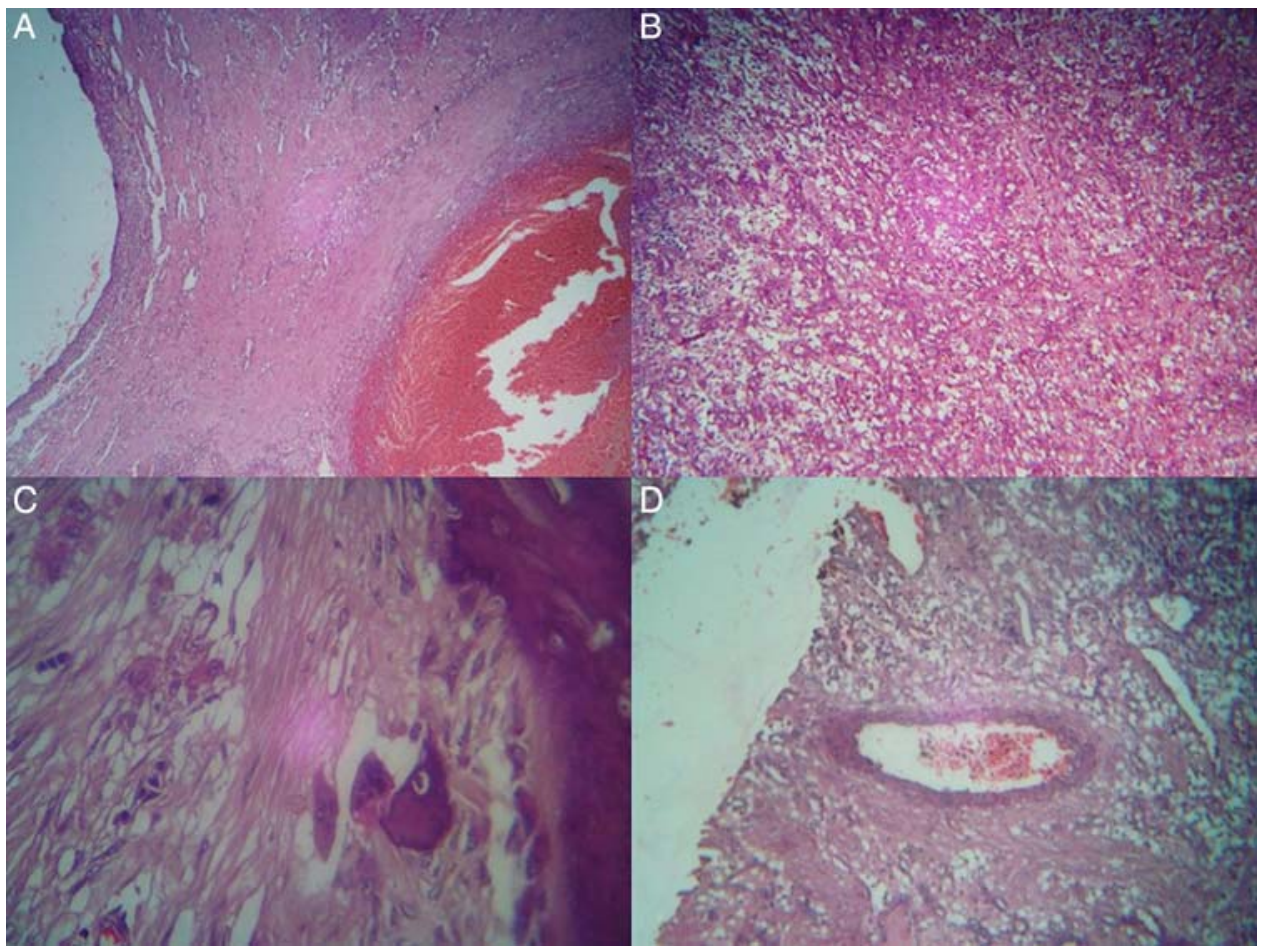

Figure 3 H\&E section showing numerous large endothelium-lined, thin-walled and thick-walled vascular spaces with erythrocytes (A, original magnification $\times 10)$, endothelial cell proliferation $(B$, original magnification $\times 40)$, giant cells in the periphery associated with resorbing bone suggestive of osteoclasts $(C$, original magnification $\times 40)$ and a large thick-walled feeder vessel is evident $(D$, original magnification $\times 40)$.

Haemangiomas may occur as a part of a variety of syndromes such as Osler-Weber-Rendu syndrome, Klippel-Trenaunay syndrome, Kasabach-Merritt syndrome, Sturge-Weber syndrome, Parkes Weber syndrome, CLOVES syndrome, Maffucci syndrome, Cobb syndrome, PHACES syndrome and Blue rubber bleb nevus syndrome. ${ }^{3}$

Large haemangiomas tend to bleed and embolisation of the feeder vessel prior to surgery reduces the risk of haemorrhage. Propanolol is an antihypertensive drug now being used successfully in treating large haemangiomas of the head and neck region, by inducing vasoconstriction and hypoxia, apoptosis of capillary endothelial cells and decreasing the angiogenic factors such as the vascular endothelial growth factor. ${ }^{4}$

A 23-year-old woman reported with swelling on the right side of the face with a growth in the right mandibular molar region for 3 months. History revealed that she had gradual swelling, mobility and exfoliation of mandibular molar teeth with limitation of mouth opening.

A diffuse swelling and facial asymmetry were seen on the right side, with an inter-incisal distance of $25 \mathrm{~mm}$. An irregular, erythematous, proliferative growth measuring $4 \times 1.5 \mathrm{~cm}$ was seen on the right mandibular alveolus (figure 1); it was ulcerated in the centre and non-tender on palpation. CT scan revealed a lytic lesion in the right mandible, with bicortical expansion, perforation and destruction of the cortical plates (figure 2). The lesion was provisionally diagnosed as a benign odontogenic neoplasm and biopsy was performed. Histological evaluation of the lesion revealed numerous large endothelium lined, thin-walled and thick-walled vascular spaces with erythrocytes, with the evidence of a large thick-walled feeder vessel (figure 3). A definitive diagnosis of cavernous haemangioma of mandible was made and subsequent hemimandibulectomy was performed.

It may be emphasised that, occasionally, haemangiomas do not bleed, thereby mimicking common odontogenic/nonodontogenic neoplasms.

\section{Learning points}

- Central haemangiomas of mandible are rare lesions.

- They present clinically as an expansile swelling with multilocular radiolucency on the radiographs, mimicking various odontogenic and non-odontogenic neoplasms.

- Central haemangiomas must be included in the differential diagnosis of multilocular jaw lesions.

\section{Competing interests None.}

Patient consent Obtained.

Provenance and peer review Not commissioned; externally peer reviewed.

\section{REFERENCES}

1 Eliot CA, Castle ET. Intraosseous hemangioma of the anterior mandible. Head Neck Pathol 2010;4:123-5.

2 Oliveira GG, García-Rozado A, Rey RL. Intraosseous mandibular hemangioma. A case report and review of the literature. Med Oral Patol Oral Cir Bucal 2008;13:E496-8.

3 Nosher JL, Murillo PG, Liszewski M, et al. Vascular anomalies: a pictorial review of nomenclature, diagnosis and treatment. World J Radiol 2014;6:677-92.

4 Zimmermann AP, Wiegand S, Werner JA, et al. Propranolol therapy for infantile haemangiomas: review of the literature. Int J Pediatr Otorhinolaryngol 2010;74:338-42. 
Copyright 2015 BMJ Publishing Group. All rights reserved. For permission to reuse any of this content visit http://group.bmj.com/group/rights-licensing/permissions.

BMJ Case Report Fellows may re-use this article for personal use and teaching without any further permission.

Become a Fellow of BMJ Case Reports today and you can:

- Submit as many cases as you like

- Enjoy fast sympathetic peer review and rapid publication of accepted articles

- Access all the published articles

- Re-use any of the published material for personal use and teaching without further permission

For information on Institutional Fellowships contact consortiasales@bmjgroup.com

Visit casereports.bmj.com for more articles like this and to become a Fellow 